\title{
Development and validation of a Professional Ethics Scale for pre-service teachers
}

\author{
Sevinç Gelmez-Burakgazi ${ }^{* a}$, İclal Can ${ }^{* * b}$ \\ ${ }^{a}$ Hacettepe University, Faculty of Education, Ankara/Turkey \\ ${ }^{\mathrm{b}}$ Middle East Technical University Northern Cyprus Campus/ Turkey
}

Article Info

DOI: $10.31704 /$ ijocis.2018.013

Article History:

Received 23 April 2018

Revised 23 July 2018

Accepted 19 October 2018

Online 27 December 2018

\section{Keywords:}

Professional ethics,

Code of ethics,

Teaching Ethics Scale.

\section{Abstract}

The purpose of this study was to develop a scale to investigate Turkish pre-service teachers' perceptions of professional ethics in teaching. This survey research consisted of two studies. In study 1, an exploratory factor analysis (EFA) was performed in SPSS 23 in order to investigate the scale's factorial structure. Study 1 involved a convenience sample of 220 senior pre-service teachers studying at two Turkish public universities. The EFA yielded a single factor structure which accounted for $39.36 \%$ of the total variance and included 43 items. In study 2, a confirmatory factor analysis (CFA) was conducted in LISREL 9.30 to test and confirm the unidimensional structure of the 43-item scale obtained in study 1 on a data set of 724 participants from four public universities. Overall, the results prove that this 43 -item scale is a valid and reliable tool to test pre-service teachers' perceptions of professional ethics.

Article Type:

Research paper

\section{Öğretmen adaylarının mesleki etik değerlerine yönelik bir ölçek geliştirme çalışması}

\section{Makale Bilgisi}

DOI: 10.31704/ijocis.2018.013

Makale Geçmişi:

Geliş $\quad 23$ Nisan 2018

Düzeltme 23 Temmuz 2018

Kabul 19 Ekim 2018

Çevrimiçi 28 Aralık 2018

\section{Anahtar Kelimeler:}

Meslek etiği,

Etik kodları,

Öğretmenlik Etik Ölçeği.

\section{Makale Türü:}

Özgün Makale

\section{Öz}

Bu çalışmanın amacı, öğretmen adaylarının mesleki etik değer algılarının belirlenmesine yönelik bir ölçeğin geliştirilmesidir. Söz konusu betimsel araştırma, iki çalışmadan oluşmaktadır. Birinci çalışmada ölçeğin faktör yapısını incelemek üzere, SPSS 23 paket programında Açımlayıcı Faktör Analizi (AFA) kullanılmıştır. Birinci çalışmanın örneklemini iki devlet üniversitesinde dördüncü sınıf düzeyinde öğrenim gören, uygun örnekleme yöntemi ile seçilen 220 öğretmen adayı oluşturmaktadır. AFA sonucunda toplam varyansın \%39.36'sını açıklayan, 43 madde ve tek faktörden oluşan bir yapı elde edilmiştir. İinci çalışmada, birinci çalışmada elde edilen 43 maddelik ölçeğin tek boyutlu yapısının test edilmesi ve doğrulanması amacıyla dört devlet üniversitesinde okuyan 724 katılımcıdan veri toplanmıştır. Sonuç olarak, araştırma sonuçları 43 maddelik bu ölçeğin, öğretmen adaylarının mesleki etik değerlerini incelemek üzere kullanılabilecek geçerli ve güvenilir bir ölçek olduğunu ortaya koymaktadır.

\footnotetext{
Author: sevincgb@hacettepe.edu.tr

** Author: iclal@metu.edu.tr
}

Orcid ID: https://orcid.org/0000-0002-4553-1433 Orcid ID: https://orcid.org/0000-0003-0466-9687 


\section{Introduction}

The development of teacher training processes has recently been the subject of much discussion within educational research. Maxwell and Schwimmer's (2016) research emphasizes teachers' role as moral models for their students from the beginning of formal teacher education. In the international literature, a recent trend has been to place greater emphasis on establishing ethical standards for the teaching profession (Barrett, Headley, Stovall \& Witte, 2006; Barrett, Casey, Visser \& Headley, 2012; Campbell, 2000; Weil, 2005) and integrating course(s) developed in accordance with these standards into teacher training programs.

Ethical standards and ethical principles for the teaching profession will help teachers make more consistent, transparent and rational decisions in different situations they encounter. However, only a limited number of studies have been conducted on this topic. The Turkish Higher Education Council's (HEC) proposal on teaching profession ethics is noteworthy within the national literature on teaching profession ethics. The HEC (2007) proposed establishing "elective courses for the training of professional ethics in teacher education programs" (p.4) like those in Europe and the US in its explanation of the programs to be implemented in HEC institutions. However, examining the courses in these higher education institutions' teacher training programs, "teaching profession ethics" is not among the compulsory courses. Instead, topics related to teaching profession ethics are generally discussed for one or two weeks as part of other education courses. Thus, standards for teaching profession ethics are needed and lessons must be developed on this topic in order to increase the quality of teacher education and thus also of students' education. In 2015, Turkey's Ministry of National Education (MoNE) established six professional ethics principles for educators, which are as follows: (1) ethical principles in relation to students, (2) ethical principles for the education profession, (3) ethical principles in relation to educators, (4) ethical principles in relation to parents, (5) ethical principles in relation to school management and society, and (6) ethical principles related to school administrators' relationships with teachers, students and parents.

Professional ethics is defined as "the totality of behaviors that the parties have to obey or avoid" (Turkish Language Association, 2016). Ethics norms shaped by values, experiences, culture and philosophy help people decide what behavior is right or wrong (Miller, 2000; Singer, 1993). Ethical studies are used to determine the standards of "good", "wanted", "loyal", "accepted", "should be supported", "right or wrong", and "acceptable and unacceptable" (Gözütok, 1999, p. 85). As in other professions, education has its own ethical principles. McKelvie-Sebileau (2011) set out principles for teaching profession ethics in 24 countries and examined the use of them. The most prominent themes were values (respect, equality, honesty, dedication, etc.); relationships with others (colleagues, students, parents, etc.); gender issues (sexual discrimination, harassment, etc.); and occupational competences (knowledge, pedagogy, etc.) (p.19). Campbell (2000) similarly emphasized the importance of teachers' actions regarding ethical principles in relation to the environment and suggested that teachers had different relationships in their working lives: with their students, with other teachers, with school administrators, with ministries, and with parents. They must act in keeping with their responsibility to all of these stakeholders. Teaching profession ethics are also referred to in Turkish higher education law. Higher Education Act No. 2547 lists among the purposes of higher education training students who are "free and respectful of scientific thinking and human rights" (Article 5) and "balanced and healthy in spirit, morality and feeling" (Article 6) (p. 5350).

Pre-service teachers should be able to define ethical and unethical behaviors and attitudes in the teaching profession and act accordingly. Unethical behavior by teachers can lead students to interpret these behaviors as appropriate or correct even though they are not. For this reason, teachers should demonstrate ethical behavior and serve as role models. Carrying out studies on professional ethics in teacher education is of great importance, since teachers are role models for their students through their attitudes and behaviors and influence their students' ethical development indirectly or directly. Unfortunately, ethical rules for teachers are not generally written down. The development of professional ethics principles can be seen as a sign of the profession's maturation (Lovat, 1998, p. 4) and can guide professional practitioners (Haynes, 1998, p.42). Barrett et al. (2006, p. 422; 2012, p. 891) addressed the lack of standardized professional ethics principles and criticized the existence of different ethical principles in different US states. The need for additional studies in this regard was also mentioned by Campbell (2000). Culture has been observed to shape people's behaviors and interactions. McKelvie-Sebileau (2011) stated that the codes of the teaching profession developed in different countries, regions or provinces take on different tones and address different phenomena (e.g. social media use), but have similar general qualities.

A number of scales measuring teachers' perceptions of professional ethics exists (Aydoğan, 2011; Barrett et al., 2006; 2012; Forsyth, 1980; Gözütok, 1999; Kumar \& Kaur, 2014; Özbek, 2003; Öztürk Aynal, Kumandaş \& 
Ersanlı, 2013; Pelit \& Güçer, 2006; Poisson, 2009; Sevim, 2014; Tabachnick, Keith-Spiegel \& Pope, 1991; Yılmaz, 2005). These scales mainly have a multi-dimensional factor structure except one (Aydoğan, 2011). To illustrate, Barrett et al. (2006) developed a scale to detect teachers' perceptions of professional ethics with a threedimensional structure: boundary violations, non-professional inattentive (behavior), and subjective evaluation. Barrett et al. (2012) further refined this three-factor structure and applied it to social media. The three factors identified were as follows: boundary violations, carelessness in teaching, and subjective assessment. Öztürk Aynal, Kumandaş and Ersanlı (2013) applied a four-dimensional structure in their ethical scale for preschool teachers: the teacher's responsibilities to himself/herself and the child, the teacher's responsibilities to the profession and to his/her colleagues, the teacher's responsibilities to families and to society, and the teacher's responsibilities to children with special education needs. In another study, Pelit and Güçer (2006) developed a three-dimensional scale for teacher candidates encompassing relations to students, to the teaching profession (job-related responsibility) and to colleagues.

Currently, international scales are usually developed for teachers working in different countries and cultures (Barrett et al., 2006; 2012; Keith-Spiegel \& Pope, 1991; Kumar \& Kaur, 2014; Poisson, 2009; Tabachnick, Keith-Spiegel \& Pope, 1991). The scales developed in Turkey are generally related to specific teaching fields (Aynal, Kumandaş \& Ersanlı, 2013; Özbek, 2003) and/or do not contain material related to technology and/or the changing nature of media use (Gözütok, 1999; Pelit \& Güçer, 2006; Yılmaz, 2005). The relevant literature shows that the use of technology and social media is an important point to consider in the context of teachers' professional ethics (Barrett et al., 2006; 2012). For example, Barrett et al. (2012) consider the use of social media to be an ethics violation in their comprehensive field work on teacher ethics. They refer to studies in different countries finding out that the unethical use of social media causes teachers to be fired or suspended from their work. This highlights the importance of addressing social media and technology in ethical rules.

Examining the national and international literature makes clear the need for a scale measuring pre-service teachers' perceptions of professional ethics, considering social, cultural and technological changes. Thus, the aim of this study was to develop a scale to determine pre-service teachers' perceptions of professional ethics in faculties of education in Turkey.

\section{Method}

Survey research study design which is one of the mostly used designs in social sciences as well as psychology and health was employed in this study. Data were collected from a large group of pre-service teachers in Study 1 and in Study 2.

\section{Study 1: Initial Scale Development and Exploratory Factor Analysis}

\section{Item generation}

An item pool regarding pre-service teachers' perceptions of professional ethics in three successive and complementary steps was generated. A thorough review of the relevant literature, examination of codes of ethics in teacher education in different countries (Australia, Canada, France, Netherlands, UK, USA) as well as in Turkey, and analysis of the existing scales currently used to assess teachers' perceptions of professional ethics were carried out initially. In the second stage, structured brainstorming sessions on the "key characteristics of good teachers" and "acceptable/unacceptable behaviors in the teaching profession" with pre-service teachers from different departments at two different major Turkish universities were held. In the final stage, the item pool was generated on the basis of (a) the basic concepts in the literature, (b) existing scales on teachers' professional ethics (Barrett et al. 2006, 2012; Gözütok, 1999; Keith-Spiegel \& Pope, 1991; Kumar \& Kaur, 2014; Pelit \& Güçer, 2006; Poisson, 2009; Sevim, 2014; Tabachnick, Ei \& Bowen, 2002; Yılmaz, 2005), (c) the results of the brainstorming sessions held with pre-service teachers, (d) codes of professional ethics for teachers established by the MoNE (2015), (e) cultural values and norms, and (f) our professional experience as teacher educators. After eliminating parallel items, a pool of 67 items on a Likert Scale ranging from 1 (Definitely unethical) to 5 (Definitely ethical) was generated.

\section{Content and face validity}

After the items were written, expert feedback from four university faculty members in Measurement and Evaluation, two faculty members in Curriculum and Instruction, one faculty member in Turkish Language and Literature (total seven experts), and three teachers was obtained in order to ensure content and face validity. 
The experts focused on the clarity of the instructions and items as well as the items' appropriateness in measuring pre-service teachers' perceptions of professional ethics. In addition to the experts, we asked two pre-service teachers to review the scale using a think-aloud protocol. Just like the experts, the teacher candidates commented on the clarity of the instructions and items as well as the items' appropriateness for measuring the construct and suggested an estimated duration for the scale. The scale was modified based on the experts' and students, reviews, and had 60 items at the end of the revision process.

\section{Procedure}

The data collection process took place from April 2016 to February 2017. The scale was administered to 220 pre-service teachers in their final year of teacher education at two major public universities in Ankara, Turkey, during class hours and with the permission of course instructors. The pre-service teachers were given information about the study and participated in the study on a voluntary basis. They were asked to provide demographic information on their gender and department and to mark the extent to which they found the statements in the scale to be ethical.

\section{Participants}

The study's sample encompassed 220 pre-service teachers (175 female, 45 male) in their final year of university (seniors) enrolled in different majors at two major public universities in Ankara, Turkey. The reason seniors were selected as participants is that they had already completed all educational courses and thus likely had more awareness of professional ethics in teaching than students in earlier years. Convenience sampling was used to recruit the participants in two different public universities. In this study, we tried to obtain the largest possible number of participants, as suggested by Henson and Roberts (2006). Table 1 presents the demographics of the study participants. The students were majoring in classroom teaching ( $n=92$ ), English language teaching $(n=41)$, mathematics education $(n=15)$, computer education and instructional technologies $(n=14)$, early childhood education $(n=13)$, guidance and psychological counseling $(n=13)$, science and technology teaching $(n=11)$, physical education and sports, $(n=9)$, German language teaching $(n=7)$, French language teaching $(n=4)$, and physics education $(n=1)$.

Table 1.

Distribution of the Participants by Gender and the Department.

\begin{tabular}{|c|c|c|c|c|c|}
\hline & & \multicolumn{2}{|c|}{$\begin{array}{c}\text { University A } \\
(n=182)\end{array}$} & \multicolumn{2}{|c|}{$\begin{array}{c}\text { University B } \\
(n=38)\end{array}$} \\
\hline & & $N$ & $\%$ & $N$ & $\%$ \\
\hline \multirow[t]{2}{*}{ Gender } & Male $(n=45)$ & 35 & 19.20 & 10 & 26.30 \\
\hline & Female $(n=175)$ & 147 & 80.80 & 28 & 73.70 \\
\hline \multirow[t]{11}{*}{ Department } & Classroom Teaching ( $n=92)$ & 92 & 50.50 & 0 & .00 \\
\hline & English Language Teaching $(n=41)$ & 29 & 15.90 & 12 & 31.60 \\
\hline & Mathematics Education $(n=15)$ & 13 & 7.10 & 2 & 5.30 \\
\hline & Computer Education and Instructional Technologies $(n=14)$ & 3 & 1.60 & 11 & 28.90 \\
\hline & Early Childhood Education ( $n=13$ ) & 6 & 3.30 & 7 & 18.40 \\
\hline & Guidance and Psychological Counseling ( $n=13)$ & 11 & 6.00 & 2 & 5.30 \\
\hline & Science and Technology Teaching $(n=11)$ & 10 & 5.50 & 1 & 2.60 \\
\hline & Physical Education and Sports ( $n=9)$ & 7 & 3.80 & 2 & 5.30 \\
\hline & German Language Teaching $(n=7)$ & 7 & 3.80 & 0 & .00 \\
\hline & French Language Teaching $(n=4)$ & 4 & 2.20 & 0 & .00 \\
\hline & Physics Education $(n=1)$ & 0 & .00 & 1 & 2.60 \\
\hline
\end{tabular}

\section{Data analysis}

SPSS 23 for Windows was used to analyze the data. An exploratory factor analysis (EFA) with maximum likelihood extraction and a varimax rotation was performed to investigate the factorial structure of the scale.

\section{Results}

Kaiser-Meyer-Olkin (KMO) test was used to measure sampling adequacy and Bartlett's test of sphericity to measure the data's suitability for factor analysis. As can be seen in Table 2, the KMO measure of sampling adequacy was .94 (>.60), suggesting that the sample size was adequate for the analysis (Tabachnick \& Fidell, 
2007). Moreover, Bartlett's test of sphericity was significant at the .00 level $(\chi 2=6332.89, D F=903, p=.00)$, indicating the suitability of the data for factor analysis (Büyüköztürk, 2004).

Table 2.

KMO and Bartlett's Tests Analysis Results.

\begin{tabular}{ll}
\hline Kaiser-Meyer-Olkin Measure of Sampling Adequacy .94 \\
\hline Bartlett's Test of & Approx. Chi-Square 6332.89 \\
Sphericity & Df. 90 \\
& Sig. .00 \\
\hline
\end{tabular}

As can be seen in Table 3, the results of the EFA with maximum likelihood extraction and a Varimax rotation showed that there were nine factors with an eigenvalue larger than 1 . The factorial structure of the scale was determined on the basis of both the conceptual framework and empirical results. The first factor accounted for 39.36 of the variance, with an eigenvalue that was 5 times larger than the eigenvalue of the second factor (2.46). This indicates that a single factor was strongly predictive of pre-service teachers' perceptions of professional ethics.

\section{Table 3.}

Total Variance Explained.

\begin{tabular}{lrrr}
\hline Factor & Total & \% of Variance & Cumulative \% \\
\hline 1 & 16.93 & 39.36 & 39.36 \\
2 & 2.46 & 5.73 & 45.10 \\
3 & 1.98 & 4.61 & 49.70 \\
4 & 1.64 & 3.80 & 53.50 \\
5 & 1.42 & 3.29 & 56.79 \\
6 & 1.31 & 3.05 & 59.84 \\
7 & 1.22 & 2.84 & 62.68 \\
8 & 1.12 & 2.61 & 65.29 \\
9 & 1.03 & 2.40 & 67.69 \\
10 & .98 & 2.27 & 69.97 \\
$:$ & $:$ & $:$ & $:$ \\
$:$ & $:$ & $:$ & $:$ \\
42 & .11 & .26 & 99.79 \\
43 & .09 & .21 & 100.00 \\
\hline
\end{tabular}

The scree plot showing the eigenvalue components (see Figure 1) revealed that there was one obvious dimension after the bending point. Including the second and third factors in the analysis revealed that the items did not cluster within these factors in a conceptual way. Thus, factor loadings below .45 were excluded from the analysis, and consecutive analyses were conducted using Varimax rotation, forcing the items to load onto a single factor. Table 4 presents the items' factor loadings, item-total correlations, and the variance they accounted for. The final scale consisted of 43 items with a uni-dimensional structure which accounted for 39.36 of the variance. 


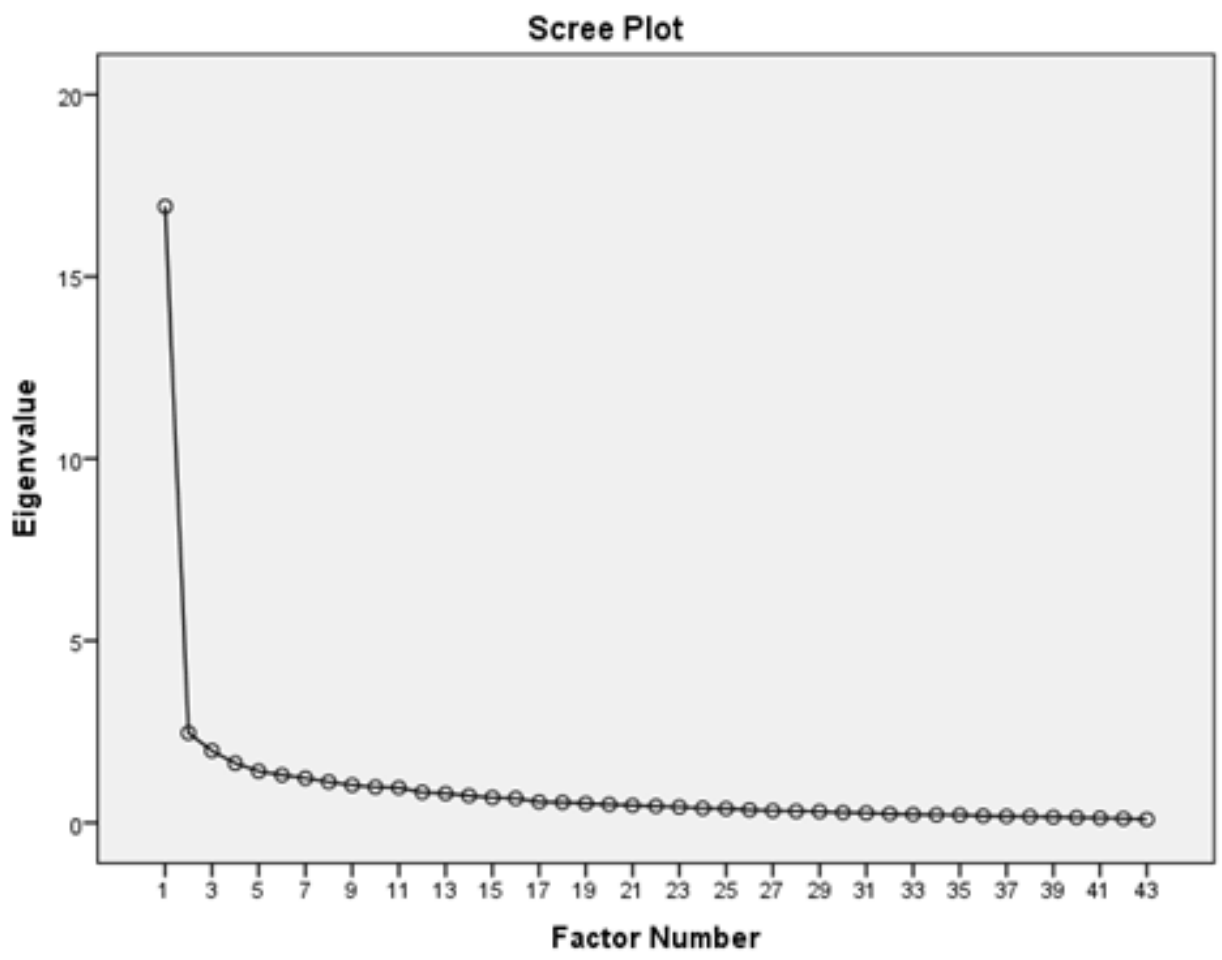

Figure 1. Scree test graphic.

Cronbach's alpha coefficient of the scale was calculated to examine the internal consistency reliability. The Cronbach's alpha coefficient of the scale was .96, above the suggested threshold level of .70 in the social sciences (Murphy \& Davidshafer, 2005). This revealed the high internal consistency reliability of this measurement tool.

\section{Discussion}

In study 1, a uni-dimensional 43-item scale to investigate pre-service teachers' ethical perceptions was developed. In order to do so, 17 items were eliminated as a result of the EFA; the remaining items were reordered and renumbered, and the instrument was finalized. Among the excluded items were "accepting gifts from the students", "not meeting dress code", and "collecting money from students". The final instrument was titled the "Professional Ethics Scale for Pre-Service Teachers". Some of the scale items are: "using school supplies for non-school purposes"; "Spending course time on unrelated activities"; and "being indifferent to the injustices students are exposed to". Responses were given a 5-point Likert-type scale: "I definitely don't find it ethical", "I don't find it ethical", "Not sure", "I find it ethical", "I definitely find it ethical".

\section{Study 2: Confirmatory Factor Analysis}

In study 2, a confirmatory factor analysis was employed using a data set of 724 participants to test and confirm the uni-dimensional structure of the 43 -item scale obtained through exploratory factor analysis in study 1.

\section{Procedure}

The data collection process took place from October to December 2017. The scale was administered to 724 senior pre-service teachers enrolled in different departments at four major public universities in Ankara, Turkey, during class hours and with the permission of the course instructors. Pre-service teachers were furnished with information about the study and were asked to participate on a voluntary basis. They provided demographic information on their gender and department, and were asked to mark the extent to which they found the statements in the scale to be ethical. 
Table 4.

Items' Factor Loading Scores Item,-Total Correlations and the Variance They Accounted for.

\begin{tabular}{|c|c|c|c|c|c|}
\hline Items & $\begin{array}{r}\text { Factor } \\
\text { Loadings }\end{array}$ & $\begin{array}{l}\text { Item-Total } \\
\text { Correlation }\end{array}$ & Items & Factor Loadings & $\begin{array}{l}\text { Item-Total } \\
\text { Correlation }\end{array}$ \\
\hline Item 1 & .46 & .48 & Item 23 & .48 & .44 \\
\hline Item 2 & .62 & .62 & Item 24 & .63 & .61 \\
\hline Item 3 & .49 & .47 & Item 25 & .69 & .65 \\
\hline Item 4 & .52 & .51 & Item 26 & .68 & .66 \\
\hline Item 5 & .58 & .57 & Item 27 & .73 & .70 \\
\hline Item 6 & .53 & .53 & Item 28 & .77 & .73 \\
\hline Item 7 & .57 & .55 & Item 29 & .68 & .67 \\
\hline Item 8 & .56 & .55 & Item 30 & .68 & .67 \\
\hline Item 9 & .45 & .46 & Item 31 & .76 & .73 \\
\hline Item 10 & .52 & .53 & Item 32 & .67 & .67 \\
\hline Item 11 & .57 & .57 & Item 33 & .74 & .71 \\
\hline Item 12 & .53 & .51 & Item 34 & .63 & .63 \\
\hline Item 13 & .48 & .48 & Item 35 & .51 & .51 \\
\hline Item 14 & .55 & .55 & Item 36 & .67 & .65 \\
\hline Item 15 & .73 & .72 & Item 37 & .73 & .71 \\
\hline Item 16 & .63 & .62 & Item 38 & .75 & .72 \\
\hline Item 17 & .63 & .63 & Item 39 & .64 & .63 \\
\hline Item 18 & .46 & .47 & Item 40 & .66 & .62 \\
\hline Item 19 & .48 & .50 & Item 41 & .70 & .68 \\
\hline Item 20 & .50 & .50 & Item 42 & .63 & .63 \\
\hline Item 21 & .48 & .47 & Item 43 & .71 & .69 \\
\hline Item 22 & .58 & .54 & & & \\
\hline \multicolumn{5}{|c|}{ Accounted Variance $39.36 \%$} & Total Variance 16.93 \\
\hline
\end{tabular}

\section{Participants}

724 senior pre-service teachers (596 female, 127 male) enrolled in different majors at four major public universities, including the two public universities in Study 1, in Ankara, Turkey, were involved in the study. Convenience sampling was used to recruit the participants. Table 5 presents the demographics of the study participants. The students were majoring in English language teaching $(n=197)$, early childhood education $(n=117)$, science and technology education $(n=103)$, classroom teaching $(n=93)$, mathematics education $(n=73)$, computer education and instructional technologies $(n=69)$, Turkish language teaching $(n=38)$, and primary school mathematics education $(n=33)$.

\section{Data analysis}

A confirmatory factor analysis was applied to a data set of 724 participants to test and confirm the unidimensional structure obtained in the exploratory factor analysis in study 1 . The analysis was conducted in LISREL 9.30. 
Table 5.

Distribution of the Participants by Gender and the Department ( $n=724)$.

\begin{tabular}{|c|c|c|c|c|c|c|c|c|c|}
\hline & & \multicolumn{2}{|c|}{$\begin{array}{l}\text { University A } \\
(\mathrm{N}=43)\end{array}$} & \multicolumn{2}{|c|}{$\begin{array}{c}\text { University B } \\
(\mathrm{N}=\mathbf{2 4 1})\end{array}$} & \multicolumn{2}{|c|}{$\begin{array}{c}\text { University C } \\
(\mathrm{N}=324)\end{array}$} & \multicolumn{2}{|c|}{$\begin{array}{c}\text { University } D \\
(\mathrm{~N}=116)\end{array}$} \\
\hline & & $N$ & $\%$ & $N$ & $\%$ & $N$ & $\%$ & $N$ & $\%$ \\
\hline \multirow[t]{2}{*}{ Gender } & Male $(n=127)$ & 19 & 44.20 & 31 & 12.90 & 50 & 15.40 & 27 & 23.30 \\
\hline & Female $(n=596)$ & 24 & 55.80 & 209 & 87.10 & 274 & 84.60 & 89 & 76.70 \\
\hline \multirow[t]{9}{*}{ Department } & English Language & 0 & .00 & 66 & 33.50 & 75 & 38.10 & 56 & 28.40 \\
\hline & Teaching ( $n=197)$ & & & & & & & & \\
\hline & $\begin{array}{l}\text { Early Childhood } \\
\text { Education }(n=117)\end{array}$ & 0 & .00 & 30 & 25.60 & 87 & 74.40 & 0 & .00 \\
\hline & $\begin{array}{l}\text { Science and Technology } \\
\text { Education }(n=103)\end{array}$ & 0 & .00 & 31 & 30.10 & 72 & 69.90 & 0 & .00 \\
\hline & $\begin{array}{l}\text { Classroom Teaching ( } n \\
=93 \text { ) }\end{array}$ & 0 & .00 & 33 & 35.50 & 60 & 64.50 & 0 & .00 \\
\hline & $\begin{array}{l}\text { Mathematics Education } \\
(n=73)\end{array}$ & 0 & .00 & 43 & 58.90 & 30 & 41.10 & 0 & .00 \\
\hline & $\begin{array}{l}\text { Computer Education and } \\
\text { Instructional } \\
\text { Technologies }(n=69)\end{array}$ & 43 & 62.30 & 0 & .00 & 0 & .00 & 26 & 37.70 \\
\hline & $\begin{array}{l}\text { Turkish Language } \\
\text { Teaching }(n=38)\end{array}$ & 0 & .00 & 38 & 100.00 & 0 & .00 & 0 & .00 \\
\hline & $\begin{array}{l}\text { Primary School } \\
\text { Mathematics Teaching ( } n \\
=33 \text { ) }\end{array}$ & 0 & .00 & 0 & .00 & 0 & .00 & 33 & 100.00 \\
\hline
\end{tabular}

Note: One participant did not provide gender and department information.

\section{Results}

Table 6 presents the maximum likelihood estimates for the 43-item Professional Teaching Ethics Scale; squared multiple correlations (R2) of the observed variables and $t$ values for the factor loadings showing the significance of the relationship. Figure 2 presents the confirmatory factor analysis model.

The $t$-values of all items were significant $(p<0.05)$, indicating that the relation between the latent variable and each item was significant and that no items needed to be excluded from the scale. Fit indexes demonstrated the data's suitability to the uni-dimensional model established in Study 1. Table 7 shows the fit indexes of the 43-item model of the Professional Teaching Ethics Scale.

The model fit was assessed using Hu and Bentler's (1999) two-index strategy. Standardized root mean square residual (SRMR) was used and supported by the root mean square error of approximation (RMSEA), comparative fit index (CFI), non-normed fit index (NNFI), normed fit index (NFI), and relative fit index (RFI). As can be seen in Table 7, the ratio of chi-square to degrees of freedom was $X 2(860)=3338.32, p<0.01$; the root mean square error of approximation $(R M S E A)=.06$; standardized root mean square residual $(S R M R)=.06$; comparative fit index (CFI) = .95; goodness-of-fit index (GFI) = .69; non-normed fit index (NNFI) = .94; normed fit index $(\mathrm{NFI})=.94$; relative fit index $(\mathrm{RFI})=.93$. The results indicated that the model fit the data, as all fit indexes except GFI were acceptable and suggest valid results. Figure 2 shows the path diagram of the scale items' lambda (factor-loading) values.

The Cronbach's alpha coefficient of the scale was computed to assess the internal consistency reliability. The Cronbach's alpha coefficient of the scale was .96 in study 2 as well, showing that the scale had high internal consistency reliability as a tool to assess pre-service teachers' perceptions of professional teaching ethics.

\section{Discussion}

Study 1 produced a uni-dimensional 43-item, 5-point Likert-type scale. We conducted study 2 to test the uni-dimensional structure established in study 1 . The results of study 2 confirmed that the uni-dimensional scale measured pre-service teachers' perceptions of professional ethics in teaching. The results further suggested that the scale is a valid and reliable instrument. 
Table 6.

Confirmatory Factor Analysis Results $(n=724)$.

\begin{tabular}{|c|c|c|c|}
\hline Item & Parameter Estimates & $\mathbf{R}^{2}$ & t value \\
\hline 1 & .27 & .13 & 6.94 \\
\hline 2 & .23 & .16 & 3.82 \\
\hline 3 & .21 & .08 & 3.86 \\
\hline 4 & .20 & .18 & 3.56 \\
\hline 5 & .32 & .27 & 6.03 \\
\hline 6 & .40 & .32 & 8.88 \\
\hline 7 & .21 & .26 & 3.03 \\
\hline 8 & .44 & .40 & 10.40 \\
\hline 9 & .34 & .26 & 7.30 \\
\hline 10 & .39 & .27 & 10.20 \\
\hline 11 & .44 & .33 & 12.20 \\
\hline 12 & .30 & .31 & 5.14 \\
\hline 13 & .36 & .29 & 6.39 \\
\hline 14 & .46 & .30 & 12.60 \\
\hline 15 & .41 & .51 & 9.91 \\
\hline 16 & .39 & .41 & 7.56 \\
\hline 17 & .30 & .26 & 5.18 \\
\hline 18 & .42 & .24 & 10.40 \\
\hline 19 & .45 & .37 & 10.80 \\
\hline 20 & .49 & .34 & 13.00 \\
\hline 21 & .34 & .37 & 5.65 \\
\hline 22 & .29 & .30 & 4.89 \\
\hline 23 & .30 & .38 & 4.88 \\
\hline 24 & .30 & .42 & 5.50 \\
\hline 25 & .28 & .34 & 4.92 \\
\hline 26 & .30 & .37 & 6.25 \\
\hline S27 & .38 & .37 & 8.56 \\
\hline S28 & .29 & .42 & 5.17 \\
\hline S29 & .37 & .39 & 7.50 \\
\hline S30 & .38 & .41 & 8.44 \\
\hline S31 & .36 & .47 & 8.87 \\
\hline S32 & .39 & .44 & 9.22 \\
\hline S33 & .36 & .43 & 7.18 \\
\hline S34 & .52 & .46 & 18.30 \\
\hline S35 & .51 & .37 & 13.00 \\
\hline S36 & .42 & .43 & 11.50 \\
\hline S37 & .46 & .48 & 13.40 \\
\hline S38 & .39 & .47 & 9.28 \\
\hline S39 & .48 & .45 & 16.20 \\
\hline S40 & .38 & .46 & 7.37 \\
\hline S41 & .46 & .44 & 14.10 \\
\hline S42 & .49 & .44 & 13.80 \\
\hline $\mathrm{S} 43$ & .40 & .45 & 8.14 \\
\hline
\end{tabular}




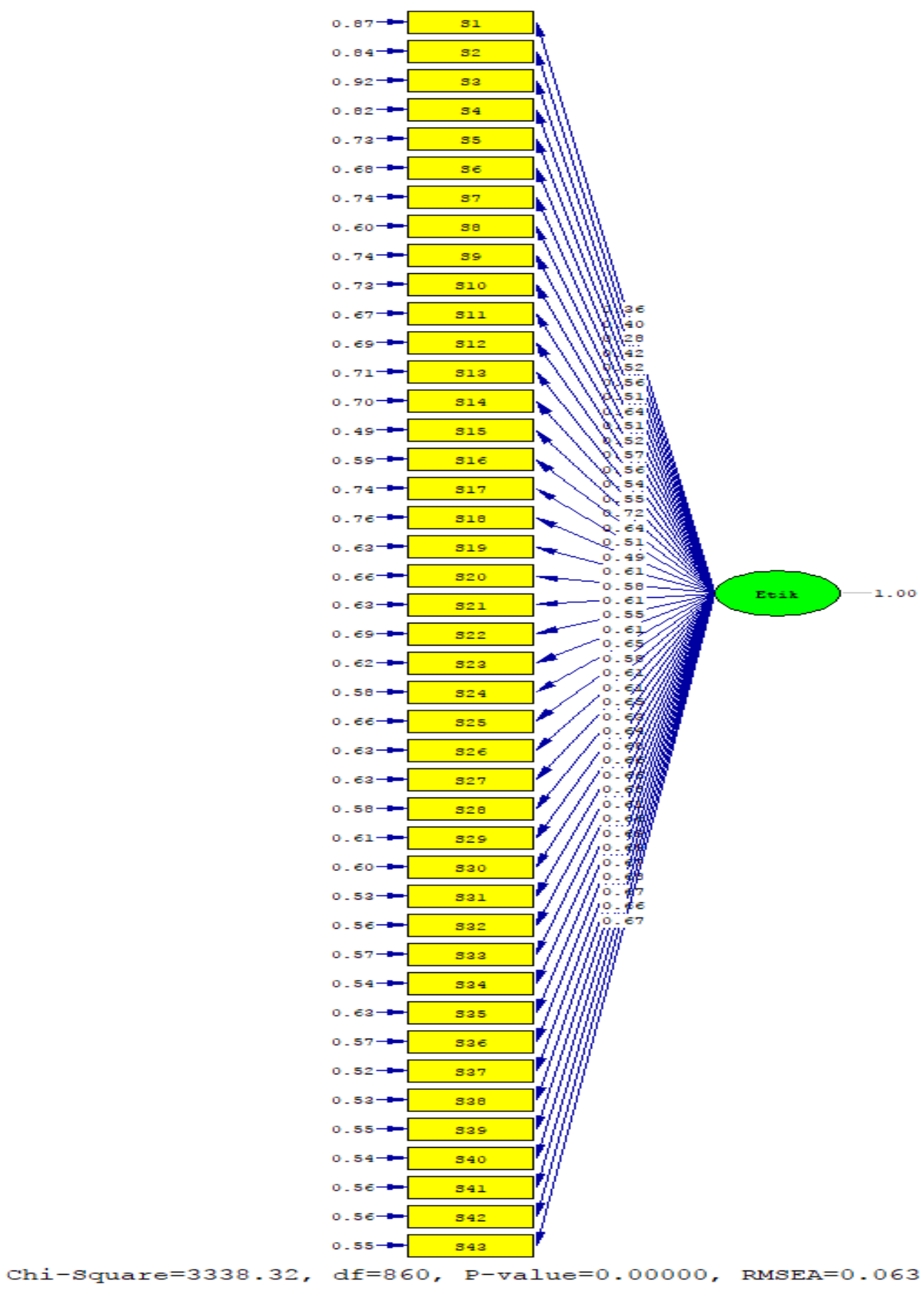

Figure 2. CFA model.

\section{General Discussion}

This research developed and validated a scale to investigate pre-service teachers' perceptions of professional ethics in teaching. To this end, a 43-item uni-dimensional scale was developed in accordance with the relevant literature, existing scales assessing teaching professional ethics, the results of the brainstorming sessions held with the pre-service teachers, codes of professional ethics for teachers established by the MoNE (2015), cultural values and norms, and our professional experience as teacher educators. 
Table 7.

Goodness Fit Indices of Professional Teaching Ethics Scale Items.

\begin{tabular}{llr}
\hline Goodness Fit Indices & Acceptable & Value \\
\hline$X^{2} /$ sd & $<5$ Medium level fit & $3338.32 / 860=3.88$ \\
& $<3$ Good level fit & \\
GFI & $>0.90$ & .69 \\
CFI & $>0.90$ & .95 \\
NFI & $>0.90$ & .94 \\
NNFI & $>0.90$ & .94 \\
RFI & $>0.85$ & .93 \\
S-RMR & $<0.08$ & .06 \\
RMSEA & $<0.08$ & .06 \\
\hline
\end{tabular}

Note: $\mathrm{GFI}=$ goodness-of-fit index; $\mathrm{CFI}=$ comparative fit index; NFI = the normed fit index; NNFI = non-normed fit index; RFI $=$ the relative fit index; SRMR = standardized root mean square residual; RMSEA = root mean square error of approximation

The development and validation of the scale was carried out in two studies. Study 1 produced a single factor scale that accounted for $39.36 \%$ of the variance with an eigenvalue that was 5 times larger than the eigenvalue of the second factor. Among the items eliminated were lending students money, accepting gifts from the students, collecting money from students, and being friends with students on social networking sites such as Facebook. These results might be explained in part by the relationship between culture and ethics (Sorokin, 2017). As Hofstede (1983) defines culture as "collective mental programming" and cultural norms can affect and shape ethical codes. Thus, it seems possible that the eliminated items mostly did not work in the Turkish context as Turkish pre-service teachers might have found the items mostly right. These results further support the idea of McKelvie-Sebileau (2011) who suggests that codes of teaching profession might take on different tones and different phenomena in different countries.

In study 2, the uni-dimensional scale produced in study 1 was tested and confirmed via confirmatory factor analysis. The results indicate that the model fit the data, as all fit indexes except GFI were acceptable. According to the results of study 1 and study 2, the 43-item scale is a valid and reliable tool for examining preservice teachers' perceptions of professional ethics. The Cronbach's alpha coefficient of the scale was .96 in both studies 1 and 2, indicating high internal consistency reliability.

In the literature, there exist many scales exploring teachers' ethical perceptions (Aydoğan, 2011; Barrett, 2006; 2012; Kumar \& Kaur, 2014; Özbek, 2003; Öztürk Aynal, Kumandaş \& Ersanlı, 2013; Kumar \& Kaur, 2014; Poisson, 2009; Sevim, 2014; Tabachnick, Keith-Spiegel \& Pope, 1991; Yılmaz, 2005) with a limited focus on preservice teachers (Gözütok, 1999; Pelit \& Güçer, 2006; Yılmaz \& Altınkurt, 2009). In contrast to the earlier studies which suggest a multi-dimensional structure to assess pre-service teachers' ethical perceptions, this study proposes a uni-dimensional structure to investigate pre-service teachers' ethical perceptions, which is consistent of that of Aydoğan (2011) who collected data from a Turkish context.

This scale can be used to develop interventions and/or training programs to increase pre-service teachers' awareness of professional ethics. It could be initially used to identify pre-service teachers' perceptions of teaching professional ethics, with the results used to develop specific interventions and/or trainings. A limitation of this study is that participants in Study 1 and Study 2 were selected using convenience sampling, which limits the generalizability of the results. In future studies, the scale can be administered to larger samples using random sampling techniques.

\section{Acknowledgement}

A part of this study was presented at the 4th International Congress on Curriculum and Instruction (ICCIEPOK, 27-30 October 2016, Antalya, Turkey). 


\section{TÜRKÇE SÜRÜM}

\section{Giriş}

Öğretmen eğitimi süreçlerinin geliştirilmesi üzerine yapılan tartışmalar son zamanlarda eğitim araştırmalarının çıkış noktasını oluşturmaktadır. Maxwell ve Schwimmer'in (2016) araştırması, öğretmenlerin örgün öğretmen eğitiminin başlangıcından itibaren öğrencilerine yönelik ahlaki modeller olarak rolünü vurgulamaktadır. Uluslararası alan yazında, öğretmenlik meslek etiğine yönelik standartların oluşturulması (Barrett, Headley, Stovall \& Witte, 2006; Barrett, Casey, Visser \& Headley, 2012; Campbell, 2000; Weil, 2005) ve bu standartlar doğrultusunda geliştirilen ders(ler)in öğretmen eğitimi programlarına entegre edilmesi hususuna vurgu yapılmıştır.

Öğretmenlik mesleğine yönelik bu tür etik standartların, etik ilkelerin ya da etik kodların geliştirilmesi, öğretmenlerin karşılaşacakları farklı durumlar karşısında daha tutarlı, şeffaf ve rasyonel karar almalarına olanak sağlayacaktır. Ancak, bu konuda yapılan çalışmaların sayısı oldukça sınırlıdır. Öğretmenlik meslek etiği üzerine yapılan ulusal alan yazın incelendiğinde, YÖK'ün öğretmenlik meslek etiği üzerine yaptığı öneri dikkat çekmektedir. YÖK'ün (2007) eğitim fakültelerinde uygulanacak programlar hakkındaki açıklamasına göre, “Avrupa'da ve Amerika'da öğretmen eğitimi programlarında yer alan meslek etiğinin kazandırılmasına yönelik seçmeli derslerin açılması" önerilmektedir (p. 4). Ancak, eğitim fakülteleri öğretmen yetiştirme programlarında bulunan dersler incelendiğinde, "öğretmenlik meslek etiği" adı altında bir dersin zorunlu dersler arasında olmadığı ve öğretmenlik meslek etiği ile ilgili konuların genellikle diğer eğitim dersleri çatısı altında bir veya iki haftalık ders saati süresince tartışıldığı görülmektedir. Buradan hareketle, öğretmen eğitiminin ve dolayısıyla eğitimin kalitesini artırmak için öğretmenlik meslek etiğine yönelik standartlara ve bu kapsamda geliştirilen derslere ihtiyaç vardır. 2015 yılında, Milli Eğitim Bakanlığı (MEB), eğitimciler için altı mesleki etik ilkesi belirlemiştir: (1) öğrencilerle ilgili etik ilkeler, (2) eğitim mesleği için etik ilkeler, (3) eğitimciler ile ilgili etik ilkeler (4) ebeveynlerle ilgili etik ilkeler, (5) okul yönetimi ve toplumla ilgili etik ilkeler ve (6) okul yöneticilerinin öğretmen, öğrenci ve velilerle olan ilişkilerine ilişkin etik ilkeler.

Etik "çeşitli meslek kolları arasında tarafların uyması veya kaçınması gereken davranışlar bütünü” olarak tanımlanmaktadır (TDK, 2016). Değerler, tecrübeler, kültür ve felsefe ile şekillenen etik normlar, hangi davranışın doğru ya da yanlış olduğu hususunda karar vermemize yardımcı olur (Miller, 2000; Singer, 1993). Etik çalışmaları sonucunda "iyi", "istendik", "kayda değer", "kabul görür", "desteklenmesi gereken", "doğru ya da yanlış", "kabul edilen ve edilemeyen" davranış standartları belirlenir (Gözütok, 1999, p. 85). Diğer mesleklerde olduğu gibi, öğretmen eğitimi de kendi etik kodlarına sahiptir. McKelvie - Sebileau'nun (2011) 24 ülkede öğretmenlik meslek etiğine yönelik kodları belirlediği ve kullanımını incelediği çalışmasında kabul edilir/doğru öğretmen davranışları arasında öne çıkan temaları sırasıyla değerler (saygı, eşitlik, dürüstlük, adanmışlık, vb.); diğerleri ile ilişkiler (meslektaşlar, öğrenciler, veliler, vb.); cinsiyet konuları (cinsel ayrımcılık, taciz, vb.); ve mesleki yeterlilikler (bilgi, pedagoji, vb.) olarak sınıflanmıştır (p. 19). Campbell (2000) paralel bir görüşle öğretmenlerin çevresi ile olan ilişkilerinde etik kodlar çerçevesinde hareket etmesinin önemine değinerek, öğretmenlerin, çalışma hayatlarında öğrencileri ile, diğer öğretmenler, okul yöneticileri, bakanlık, ebeveynler, toplum ve birey olarak kendileri de dâhil olmak üzere farklı ilişkiler yürüttüklerini ve bu paydaşlardan sorumlu hareket etmek durumunda olduklarını belirtmiştir. Öğretmenlik meslek etiği ile ilgili ifadeler YÖK kanununda da yer almaktadır. 2547 Sayılı Yükseköğretim Kanunu'na göre, yükseköğretimin amaçları arasında öğrencilerin "hür ve bilimsel düşünce gücüne, insan haklarına saygılı" (Madde 5); "ruh, ahlak ve duygu bakımından dengeli ve sağlıklı şekilde gelişmiş" (Madde 6) yetiştirilmesi hedeflenmektedir (p. 5350).

Genel itibarıyla, öğretmen adayları öğretmenlik meslek etiğinde etik olan ve olmayan davranış ve tutumları tanımlamak ve buna göre hareket etmek durumundadır. Öğretmenlerin etik olmayan davranışları, öğrencileri bu davranışların uygun ya da doğru olduğuna dair bir yanlışa yönlendirebilmektedir. Bu nedenle, öğretmenler rol-model olarak etik davranışlar göstermek durumundadır. Öğretmenlerin, tutum ve davranışlarıyla öğrencilerine rol model oldukları ve öğrencilerinin etik gelişimlerini dolaylı veya dolaysı olarak etkiledikleri düşünüldüğünde, öğretmen eğitiminde meslek etiği ile ilgili çalışmaların yapılması büyük önem taşımaktadır. Ancak, ne yazık ki öğretmenler için bu kurallar genel olarak yazılı değildir. Mesleki etik kodlarının geliştirilmesi, meslekteki olgunlaşmanın bir işareti olarak görülebileceği gibi (Lovat, 1998, p. 4); mesleği icra edenlere rehber olması yönüyle de (Haynes, 1998, p. 42) önem taşımaktadır. Barrett ve diğ. (2006, p. 422; 2012, p. 891) mesleki etik kodlarını standart hale getirmeye yönelik çalışmaların azlığına değinmiş, Amerika'da farklı eyaletlerde farklı 
etik kodu uygulamalarının varlığını eleştirmişlerdir. Bu konuda yapılacak çalışmalara duyulan ihtiyaç Campbell (2000) tarafından da dile getirilmiştir. Kültürün, insanların birbirlerine karşı davranışlarını ve etkileşimlerini şekillendirici özelliğinden hareketle, McKelvie - Sebileau (2011) tarafından da belirtildiği gibi öğretmenlik meslek etiği kodları farklı ülkelerde, bölgelerde ya da eyaletlerde farklı tonlarda ve kodlarda (örn: sosyal medya kullanımı) ancak genel anlamda benzer niteliklerle geliştiği gözlemlenmektedir.

Öğretmenlerin öğretmenlik meslek etiğine yönelik algılarını tespit etmeye yönelik çok sayıda ölçek bulunmaktadır (Aydoğan, 2011; Barrett et al., 2006; 2012; Forsyth, 1980; Gözütok, 1999; Kumar \& Kaur, 2014; Özbek, 2003; Öztürk Aynal, Kumandaş \& Ersanlı, 2013; Pelit \& Güçer, 2006; Poisson, 2009; Sevim, 2014; Tabachnick, Keith-Spiegel \& Pope, 1991; Yılmaz, 2005). Bu ölçekler, aralarında sadece biri hariç (Aydoğan, 2011) çok boyutlu faktör yapısındadır. Örneğin, öğretmenlerin mesleki etik algılarını tespit etmek için geliştirdikleri çalışmada, Barrett vd. (2006) ölçeklerinin üç boyutlu bir yapıya sahip olduğunu belirtmektedirler. Bu faktörler sınır ihlali, profesyonel olmayan dikkatsiz (davranışlar) ve öznel değerlendirme olarak gruplanmıştır. Barrett vd. (2012) aynı ölçeği sosyal medyayı da kapsayacak şekilde geliştirip uyguladıkları bir diğer çalışmalarında yine üç faktörlü bir yapı dikkat çekmektedir. Bu faktörler, birinci çalışmada ortaya çıkan faktörlerle benzerlik göstermektedir ve sırasıyla şöyledir: sınır ihlali faktörü, öğretimde dikkatsizlik ve öznel değerlendirme. Okul öncesi öğretmenleri için geliştirdikleri etik ölçeği çalışmasında, Öztürk Aynal, Kumandaş ve Ersanlı (2013) ölçeğin dört boyutlu bir yapıdan oluştuğunu belirtmektedir. Bu faktörler öğretmenin çocuğa ve kendisine karşı sorumlulukları, öğretmenin meslek ve meslektaşına karşı sorumlulukları, öğretmenin aileye ve topluma karşı sorumlulukları, öğretmenin özel eğitime gereksinimi olan çocuklarla ilgili sorumlulukları olarak adlandırılmıştır. Bir başka çalışmada ise, Pelit ve Güçer (2006), öğretmen adaylarına yönelik geliştirdikleri ölçeğin öğrencilerle ilişkiler, öğretmenlik mesleği (görevle ilgili sorumluklar) ve meslektaşlarla ilişkiler olmak üzere üç boyuttan oluştuğunu raporlamışlardır.

Mevcut uluslararası alan yazında ölçekler genellikle farklı ülkelerde ve kültürlerde görev yapmakta olan öğretmenler için geliştirilmiştir (Barrett et al., 2006; 2012; Keith-Spiegel \& Pope, 1991; Kumar \& Kaur, 2014; Poisson, 2009; Tabachnick, Keith-Spiegel \& Pope, 1991). Ülkemizde geliştirilen ölçekler de genellikle belli öğretmenlik branşlarına yöneliktir (Aynal, Kumandaş \& Ersanlı, 2013; Özbek, 2003) ve/ya çoğunlukla teknoloji ve değişen medya kullanımı ile ilgili maddeleri içermemektedir (Gözütok, 1999; Pelit \& Güçer, 2006; Sevim, 2014; Yılmaz, 2005). İlgili alan yazın, öğretmen etiği kapsamında değerlendirilmesi gereken önemli bir noktanın teknoloji ve sosyal medya kullanımı olduğunu göstermektedir (Barrett et al., 2006; 2012). Örneğin Barrett vd. (2012) öğretmen etiği üzerine yaptıkları kapsamlı alan yazın çalışmasında öğretmenlik mesleğindeki etik kural ihlallerinden birinin sosyal medyanın kullanımı olduğunu vurgulamaktadır. Çalışmalarında, sosyal medyanın etik olmayan bir şekilde kullanımından dolayı farklı ülkelerde öğretmenlerin işlerinden çıkarıldığı veya açığa alındığı çalışmaları referans olarak göstermektedir. Bu da sosyal medya ve teknoloji kullanımının da etik kurallar çerçevesinde değerlendirilmesinin önemini vurgulamaktadır.

Ulusal ve uluslararası alan yazın incelendiğinde, öğretmen adaylarının öğretmenlik meslek etik algılarını güncel sosyal, kültürel ve teknolojik değişiklikler doğrultusunda tespit etmeye yönelik bir ölçeğe gereksinim duyulmaktadır. Bununla bağlantılı olarak bu çalışmanın amacı, Türkiye'de eğitim fakültelerinde bulunan öğretmen adaylarının meslek etiğine yönelik algılarını tespit etmek amacıyla öğretmen adaylarına özgü güncel bir ölçek geliştirmektir.

\section{Yöntem}

Bu çalışmada betimsel araştırma deseni kullanılmıştır. Betimsel araştırma deseni, psikoloji ve sağlık alanlarının yanı sıra, sosyal bilimlerde de en çok kullanılan desenlerden biridir. Bu desen aracılığıyla, çalışma 1 ve 2 'de geniş ölçekli bir grup öğretmen adayından veri toplanmıştır.

\section{Çalışma 1: Temel Ölçek Geliştirme Aşaması ve Açımlayıcı Faktör Analizi}

Birbirini izleyen ve tamamlayıcı üç aşamada öğretmen adaylarının mesleki etik değer algılarının belirlenmesine yönelik bir madde havuzu geliştirildi. Öncelikle, ilgili alan yazını kapsamlı olarak değerlendirildi. Türkiye'nin yanı sıra farklı ülkelerde (Avustralya, Kanada, Fransa, Hollanda, İngiltere, Amerika) öğretmen eğitimine yönelik etik kodları incelendi ve öğretmen adaylarının mesleki etik değer algılarını belirlemek için kullanılan mevcut ölçekler incelendi. İkinci aşamada, iki farklı büyük devlet üniversitesinde farklı branşlarda öğrenim gören öğretmen adayları ile "iyi öğretmenin temel özellikleri” ve "öğretmenlik mesleğinde doğru kabul edilebilir/edilemez davranışlar" konulu yapılandırılmış beyin fırtınası oturumları gerçekleştirildi. Son aşamada, (a) alan yazındaki temel kavramlar, (b) öğretmenlik meslek etiğine yönelik mevcut ölçekler (Barrett et al., 2006; 
2012; Gözütok, 1999; Keith-Spiegel \& Pope, 1991; Kumar \& Kaur, 2014; Pelit \& Güçer, 2006; Poisson, 2009; Sevim, 2014; Tabachnick, Ei \& Bowen, 2002; Yılmaz, 2005), (c) öğretmen adayları ile yapılan beyin fırtınası oturumlarının sonuçları, (d) MEB (2015) tarafından öğretmenler için belirlenen mesleki etik kodları, (e) kültürel değerler ve normlar ve (f) öğretmen eğitimcileri olarak mesleki tecrübemizden hareketle bir madde havuzu oluşturuldu. Birbiri ile paralel nitelikteki maddeleri elemek suretiyle, 1 (Kesinlikle etik bulmuyorum) ile 5 (Kesinlikle etik buluyorum) arasında değişen 5’li Likert tipi 67 maddelik bir madde havuzu elde edildi.

\section{İ̧erik ve Görünüş Geçerliği}

Maddeleri yazdıktan sonra, içerik ve görünüş geçerliğini sağlamak amacıyla, Ölçme ve Değerlendirme ana bilim dalından dört öğretim üyesi, Eğitim Programları ve Öğretim ana bilim dalından iki öğretim üyesi, Türk Dili ve Edebiyatı anabilim dalından bir öğretim üyesi (toplam yedi uzman) ve üç öğretmenden uzman görüşü alındı. Uzmanlar, maddelerin öğretmen adaylarının mesleki etik değer algılarının belirlenmesine uygunluğunun yanı sıra yönlendirmelerin ve maddelerin açıklı̆ı üzerine görüş bildirdiler. Uzmanların yanı sıra, iki öğretmen adayından da sesli düşünme protokolü kullanarak ölçeği değerlendirmesi istendi. Uzmanlar gibi, öğretmen adayları da ölçeğin kavramı ölçmesi hususundaki uygunluğunun yanı sıra, ölçekteki yönergelerin ve maddelerin açıklı̆̆ üzerine görüş bildirdiler ve ölçeğin yanıtlanmasına yönelik süre bazında değerlendirme yaptılar. Ölçek, uzmanların ve öğrencilerin görüşleri ışığında revize edildi ve revizyon süreci sonrasında 60 maddelik bir ölçek elde edildi.

\section{Veri Toplama Süreci}

Veri toplama süreci, Nisan 2016 ve Şubat 2017 tarihleri arasında gerçekleştirilmiştir. Ölçek, Ankara, Türkiye'de bulunan iki büyük devlet üniversitesinde ders saatleri içinde, ders yürütücülerinden alınan izinler doğrultusunda uygulanmıştır. Öğrenciler çalışma hususunda bilgilendirilmiş, gönüllülük esasına göre uygulama gerçekleştirilmiştir. Katılımcılardan, cinsiyetleri ve bölümleri ile ilgili demografik bilgi vermeleri ve ölçekte belirtilen ifadeleri ne kadar etik buldukları ile ilgili yanıtlarını işaretlemeleri istenmiştir.

\section{Katılımcılar}

Araştırmanın örneklemini, Türkiye'de Ankara ilindeki iki devlet üniversitesinde son sınıf düzeyinde farklı branşlarda öğrenim gören toplam 220 (175 Kadın; 45 Erkek) öğretmen adayı oluşturmaktadır. Son sınıf öğrencilerinin katılımcı olarak seçilmesinin sebebi, bu öğrencilerin tüm eğitim derslerini tamamlamış olmaları ve buradan hareketle, önceki sınıflardaki öğrencilere kıyasla, öğretmenlik mesleği etiği hususunda daha fazla farkındalığa sahip olabilecekleri düşüncesidir. ỉki devlet üniversitesindeki katılımcıları çalışmaya dahil etmek için uygun örnekleme yöntemi kullanılmıştır. Bu çalışmada, Henson ve Roberts'ın (2006) önerdiği gibi, ulaşılabilecek en büyük katılımcı sayısı elde edilmeye çalışılmışır. Tablo 1, katılımcıların demografik özelliklerini göstermektedir. Öğrenciler, sınıf öğretmenliği $(n=92)$, İngilizce öğretmenliği $(n=41)$, matematik öğretmenliği $(n=15)$, Bilgisayar ve Öğretim Teknolojileri Eğitimi $(n=14)$, Okul Öncesi Öğretmenliği $(n=13)$, Rehberlik ve Psikolojik Danışmanlık ( $n=13)$, Fen ve Teknoloji öğretmenliği $(n=11)$, Beden Eğitimi ve Spor Öğretmenliği $(n=9)$, Almanca Öğretmenliği $(n=7)$, Fransızca Öğretmenliği $(n=4)$, ve Fizik Öğretmenliği $(n=1)$ bölümlerinde öğrenim görmekte idi.

\section{Veri Analizi}

Veri analizi SPSS 23 paket programı ile gerçekleştirilmiştir. Ölçeğin faktör yapısını belirlemek amacıyla, maximum olasııık çıkarması ve Varimax döndürme tekniği ile açımlayıcı faktör analizi (AFA) yapıımıştır.

\section{Bulgular}

Veri setinin faktör analizi için yeterli olup olmadığını tespit etmek amacıyla Kaiser-Meyer-Olkin (KMO) örneklem yeterlilik testi ve verinin faktör analizine uygunluğunu tespit etme amacıyla Bartlett'in Küresellik Testi kullanılmıştır. Tablo 2'de görüldüğü üzere, 43 maddelik ölçek için elde edilen KMO örneklem yeterlilik değeri .94 (>.60) olarak bulunmuştur. Bu değer, örneklem sayısının analiz için yeterli olduğunu göstermektedir (Tabachnick \& Fidell, 2007). Ayrıca, Bartlett'in küresellik testi .00 değerinde manidardır ( $\chi 2=6332.89, \mathrm{df}=903$, $\mathrm{p}=.00$ ). Bu bulgu verinin faktör analizine uygun olduğunu ortaya koymaktadır (Büyüköztürk, 2004). 
Tablo 1.

Katılımcıların Cinsiyet ve Bölüme Göre Dağılımları $(n=220)$.

\begin{tabular}{|c|c|c|c|c|c|}
\hline & & \multicolumn{2}{|c|}{$\begin{array}{c}\text { Üniversite A } \\
(n=182)\end{array}$} & \multicolumn{2}{|c|}{$\begin{array}{c}\text { Üniversite B } \\
(n=38)\end{array}$} \\
\hline & & $N$ & $\%$ & $N$ & $\%$ \\
\hline \multirow[t]{2}{*}{ Cinsiyet } & Erkek $(n=45)$ & 35 & 19.20 & 10 & 26.30 \\
\hline & Kadın $(n=175)$ & 147 & 80.80 & 28 & 73.70 \\
\hline \multirow[t]{11}{*}{ Bölüm } & Sınıf Öğretmenliği ( $n=92)$ & 92 & 50.50 & 0 & .00 \\
\hline & İngilizce Öğretmenliği $(n=41)$ & 29 & 15.90 & 12 & 31.60 \\
\hline & Matematik Öğretmenliği $(n=15)$ & 13 & 7.10 & 2 & 5.30 \\
\hline & Bilgisayar ve Öğretim Teknolojileri Eğitimi $(n=14)$ & 3 & 1.60 & 11 & 28.90 \\
\hline & Okul Öncesi Öğretmenliği (n=13) & 6 & 3.30 & 7 & 18.40 \\
\hline & Rehberlik ve Psikolojik Danışmanlık ( $n=13$ ) & 11 & 6.00 & 2 & 5.30 \\
\hline & Fen ve Teknoloji Öğretmenliği $(n=11)$ & 10 & 5.50 & 1 & 2.60 \\
\hline & Beden Eğitimi ve Spor Öğretmenliği $(n=9)$ & 7 & 3.80 & 2 & 5.30 \\
\hline & Almanca Öğretmenliği ( $n=7)$ & 7 & 3.80 & 0 & .00 \\
\hline & Fransızca Öğretmenliği $(n=4)$ & 4 & 2.20 & 0 & .00 \\
\hline & Fizik Öğretmenliği $(n=1)$ & 0 & .00 & 1 & 2.60 \\
\hline
\end{tabular}

Tablo 2

KMO ve Bartlett's Testi Analiz Sonuçları.

\begin{tabular}{ll}
\hline Kaiser-Meyer-Olkin Örnekleme Yeterliği Ölçümü .93 \\
\hline Bartlett's Testi & Yaklaşık Chi-Square 6332.89 \\
& Serbestlik derecesi 903 \\
& Önemlilik .00 \\
\hline
\end{tabular}

Tablo 3’te görüldüğü gibi, maksimum olasılık çıkarması ve Varimax döndürme tekniği ile yapılan açımlayıcı faktör analizi sonuçları, özdeğeri 1'den büyük olan 9 faktör olduğunu göstermektedir. Ölçeğin faktör yapısına hem kavramsal çerçeve hem de ampirik sonuçlar doğrultusunda karar verilmiştir. Birinci faktörün açıkladığı toplam varyans 39.36 olup, bu faktörün özdeğeri (16.93) ikinci faktörün özdeğerinden (2.46) 5 kat büyüktür. Bu da tek bir boyutun güçlü bir şekilde, öğretmen adaylarının mesleki etik algılarını yordadığını göstermektedir.

\section{Tablo 3.}

Faktörlerin Açıkladığı Varyanslar.

\begin{tabular}{lrrr}
\hline Faktör & Özdeğerler & Varyans Yüzdesi & Toplam Varyans Yüzdesi \\
\hline 1 & 16.93 & 39.36 & 39.36 \\
2 & 2.46 & 5.73 & 45.10 \\
3 & 1.98 & 4.61 & 49.70 \\
4 & 1.64 & 3.80 & 53.50 \\
5 & 1.42 & 3.29 & 56.79 \\
6 & 1.31 & 3.05 & 59.84 \\
7 & 1.22 & 2.84 & 62.68 \\
8 & 1.12 & 2.61 & 65.29 \\
9 & 1.03 & 2.40 & 67.69 \\
10 & .98 & 2.27 & 69.97 \\
$:$ & $:$ & $:$ & $:$ \\
$:$ & $:$ & $:$ & $:$ \\
42 & .11 & .26 & 99.79 \\
43 & .09 & .21 & 100.00 \\
\hline & & &
\end{tabular}


Özdeğer bileşenlerini gösteren Scree Plot Grafiği, kııılma noktasından sonra belirgin tek bir boyut olduğunu göstermektedir. Birinci faktörden sonraki iki ve üç faktör dikkate alınarak yapılan analizlerde maddelerin kavramsal açıdan birden fazla faktör altında toplanmadığı görülmüştür. Bu doğrultuda, faktör yükü .45 'ten küçük maddeler analizden çıkarılmış, maddeler tek bir faktöre zorlanarak, Varimax döndürme tekniği ile art arda analizler gerçekleştirilmiştir. Tablo 4, maddelerin faktör yüklerini, madde toplam korelasyonlarını ve açıkladığı varyans değerini göstermektedir. Son durumda elde edilen 43 maddelik ölçek, varyansın 39.36'sını karşılayan tek boyutlu bir yapıya sahiptir.

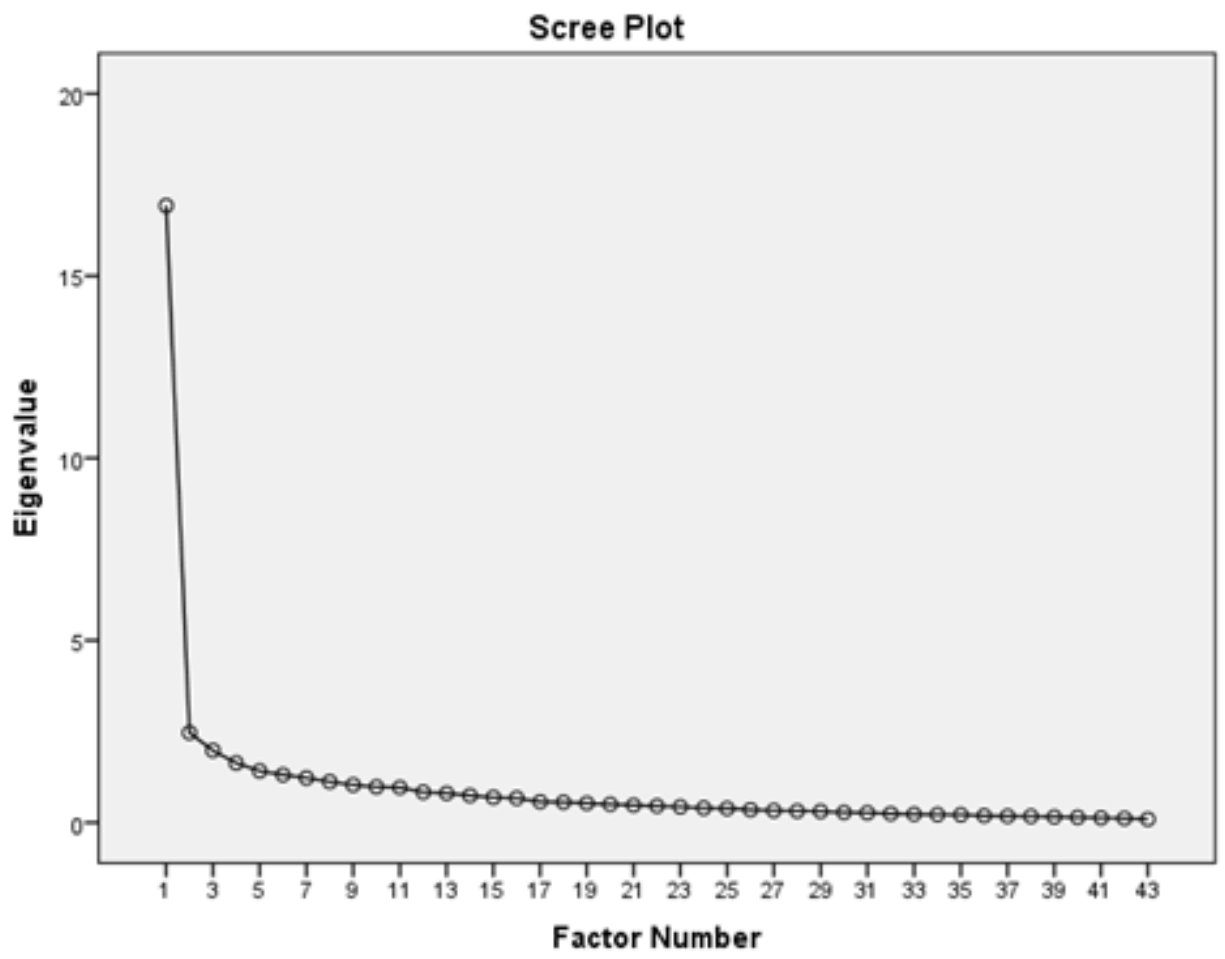

Şekil 1. Scree Plot grafiği.

Ayrıca, ölçeğin iç tutarlıık güvenirliğini saptamak amacıyla Cronbach alpha güvenilirlik katsayısı hesaplanmıştır. Ölçeğin Cronbach alpha güvenirlik katsayısı, .96 'dır. Bu bulgu, sosyal bilimler için önerilen. 70 kriterinin üstündedir (Murphy \& Davidshafer, 2005). Bu da bu ölçme aracının yüksek iç tutarlılık güvenirliğine sahip olduğunu ortaya koymaktadır.

\section{Tartışma}

Bu çalışmada, öğretmen adaylarının meslek etiğine yönelik değer algılarını tespit etmek amacıyla 43 maddelik tek boyutlu bir ölçek geliştirilmiştir. Bunu gerçekleştirmek için, AFA sonucunda 17 madde elenmiş, maddeler yeniden sıralanmış, numaralandııııış ve ölçek son haline getirilmiştir. Çıkarılan maddeler arasında, "öğrencilerden gelen hediyeleri kabul etmesi", "Okula yönetmeliğe uygun olmayan kılık - kıyafet ile gelmesi" ve "öğrencilerden her hangi bir nedenle para toplaması" bulunmaktadır. Son ölçek, "Öğretmen Adayları için Mesleki Etik Ölçeği" olarak adlandırılmıştır. Bazı ölçek maddeleri şu şekildedir: "okul malzemelerini ders dışı amaçlar için kullanması"; "ders süresini ders ile ilişkisiz etkinliklerle harcaması"; "öğrencilerin maruz kaldığı haksızıklara karşı kayıtsız kalması". Yanıtlar, 5'li Likert tipi ölçek üzerinde verilmektedir: "Kesinlikle etik bulmuyorum", "Etik bulmuyorum”, "Kararsızım”, “Etik buluyorum”, "Kesinlikle etik buluyorum”.

\section{Çalışma 2: Doğrulayıcı Faktör Analizi}

Çalışma 2'de, çalışma 1'de açımlayıcı faktör analizi ile elde edilen 43 maddelik tek boyutlu ölçeğin yapısını test etmek ve doğrulamak amacıyla 724 katılımcının olduğu bir veri seti kullanılarak doğrulayıcı faktör analizi gerçekleştirilmiştir. 
Tablo 4.

Maddelerin Faktör Yükleri, Madde Toplam Korelasyonları ve Açıkladığı Varyans Değeri.

\begin{tabular}{|c|c|c|c|c|c|}
\hline Madde & Faktör Yükü & $\begin{array}{l}\text { Madde Toplam } \\
\text { Korelasyonu }\end{array}$ & Madde & Faktör Yükü & $\begin{array}{l}\text { Madde Toplam } \\
\text { Korelasyonu }\end{array}$ \\
\hline Madde 1 & .46 & .48 & Madde 23 & .48 & .44 \\
\hline Madde 2 & .62 & .62 & Madde 24 & .63 & .61 \\
\hline Madde 3 & .49 & .47 & Madde 25 & .69 & .65 \\
\hline Madde 4 & .52 & .51 & Madde 26 & .68 & .66 \\
\hline Madde 5 & .58 & .57 & Madde 27 & .73 & .70 \\
\hline Madde 6 & .53 & .53 & Madde 28 & .77 & .73 \\
\hline Madde 7 & .57 & .55 & Madde 29 & .68 & .67 \\
\hline Madde 8 & .56 & .55 & Madde 30 & .68 & .67 \\
\hline Madde 9 & .45 & .46 & Madde 31 & .76 & .73 \\
\hline Madde 10 & .52 & .53 & Madde 32 & .67 & .67 \\
\hline Madde 11 & .57 & .57 & Madde 33 & .74 & .71 \\
\hline Madde 12 & .53 & .51 & Madde 34 & .63 & .63 \\
\hline Madde 13 & .48 & .48 & Madde 35 & .51 & .51 \\
\hline Madde 14 & .55 & .55 & Madde 36 & .67 & .65 \\
\hline Madde 15 & .73 & .72 & Madde 37 & .73 & .71 \\
\hline Madde 16 & .63 & .62 & Madde 38 & .75 & .72 \\
\hline Madde 17 & .63 & .63 & Madde 39 & .64 & .63 \\
\hline Madde 18 & .46 & .47 & Madde 40 & .66 & .62 \\
\hline Madde 19 & .48 & .50 & Madde 41 & .70 & .68 \\
\hline Madde 20 & .50 & .50 & Madde 42 & .63 & .63 \\
\hline Madde 21 & .48 & .47 & Madde 43 & .71 & .69 \\
\hline \multirow[t]{2}{*}{ Madde 22} & .58 & .54 & & & \\
\hline & & & & Açıklanan varyans $\% 39.36$ & Özdeğer16.93 \\
\hline
\end{tabular}

\section{Yöntem}

Veri toplama süreci, Ekim ve Aralık 2017 tarihleri arasında gerçekleştirilmiştir. Ölçek, Ankara, Türkiye'de bulunan dört büyük devlet üniversitesinde son sınıf düzeyinde farklı branşlarda öğrenim gören 220 öğretmen adayına, ders saatleri içinde, ders yürütücülerinden alınan izinler doğrultusunda uygulanmıştır. Öğrenciler, çalışma hususunda bilgilendirilmiş ve gönüllü öğrencilerle uygulama gerçekleştirilmiştir. Katılımcılardan, cinsiyetleri ve bölümleri ile ilgili demografik bilgiler edinilmiş ve ölçekte belirtilen ifadeleri ne kadar etik buldukları ile ilgili yanıtlarını işaretlemeleri istenmiştir.

\section{Katılımcılar}

Birinci çalışmada yer alan iki devlet üniversitesi de dahil olmak üzere, Ankara, Türkiye'de dört büyük devlet üniversitesinde son sınıf düzeyinde farklı branşlarda öğrenim gören 724 öğretmen adayı (596 kadın, 127 erkek) çalışmaya katılmıştır. Katılımcıları belirlemek için uygun örnekleme yöntemi kullanılmıştır. Tablo 5, katılımcıların demografik özelliklerini göstermektedir. Öğrenciler, İngilizce Öğretmenliği ( $n=197)$, Okul Öncesi Öğretmenliği ( $n=117)$, Fen ve Teknoloji Öğretmenliği ( $n=103)$, Sınıf Öğretmenliği $(n=93)$, Matematik Öğretmenliği $(n=73)$, Bilgisayar ve Öğretim Teknolojileri Eğitimi $(n=69)$, Türk Dili Öğretmenliği $(n=38)$ ve ilköğretim Matematik Öğretmenliği $(n=33)$ bölümlerinde öğrenim görmekte idi. 
Tablo 5.

Katılımcıların Cinsiyet ve Bölüme Göre Dağılımları ( $n=724)$.

\begin{tabular}{|c|c|c|c|c|c|c|c|c|c|}
\hline & & \multicolumn{2}{|c|}{$\begin{array}{c}\text { Üniversite A } \\
(\mathrm{N}=43)\end{array}$} & \multicolumn{2}{|c|}{$\begin{array}{c}\text { Üniversite } B \\
(\mathrm{~N}=\mathbf{2 4 1})\end{array}$} & \multicolumn{2}{|c|}{$\begin{array}{c}\text { Üniversite } \mathrm{C} \\
(\mathrm{N}=324)\end{array}$} & \multicolumn{2}{|c|}{$\begin{array}{c}\text { Üniversite D } \\
(\mathrm{N}=116)\end{array}$} \\
\hline & & $N$ & $\%$ & $N$ & $\%$ & $N$ & $\%$ & $N$ & $\%$ \\
\hline \multirow[t]{2}{*}{ Cinsiyet } & Erkek $(n=127)$ & 19 & 44.20 & 31 & 12.90 & 50 & 15.40 & 27 & 23.30 \\
\hline & Kadın $(n=596)$ & 24 & 55.80 & 209 & 87.10 & 274 & 84.60 & 89 & 76.70 \\
\hline \multirow[t]{8}{*}{ Bölüm } & İngilizce Öğretmenliği ( $n=197$ ) & 0 & .00 & 66 & 33.50 & 75 & 38.10 & 56 & 28.40 \\
\hline & Okul Öncesi Öğretmenliği ( $n=117)$ & 0 & .00 & 30 & 25.60 & 87 & 74.40 & 0 & .00 \\
\hline & $\begin{array}{l}\text { Fen ve Teknoloji Öğretmenliği } \\
(n=103)\end{array}$ & 0 & .00 & 31 & 30.10 & 72 & 69.90 & 0 & .00 \\
\hline & Sınıf Öğretmenliği $(n=93)$ & 0 & .00 & 33 & 35.50 & 60 & 64.50 & 0 & .00 \\
\hline & Matematik Öğretmenliği $(n=73)$ & 0 & .00 & 43 & 58.90 & 30 & 41.10 & 0 & .00 \\
\hline & $\begin{array}{l}\text { Bilgisayar ve Öğretim Teknolojileri } \\
\text { Eğitimi }(n=69)\end{array}$ & 43 & 62.30 & 0 & .00 & 0 & .00 & 26 & 37.70 \\
\hline & Türkçe Öğretmenliği ( $n=38$ ) & 0 & .00 & 38 & 100.00 & 0 & .00 & 0 & .00 \\
\hline & $\begin{array}{l}\text { İlköğretim Matematik Öğretmenliği } \\
(n=33)\end{array}$ & 0 & .00 & 0 & .00 & 0 & .00 & 33 & 100.00 \\
\hline
\end{tabular}

Not. Bir katııımcı cinsiyet ve bölüm bilgilerine dair soruları yanıtlamamıştır.

\section{Veri Analizi}

Çalışma 1'de açımlayıcı faktör analizi ile elde edilen tek boyutlu yapıyı test etmek ve doğrulamak amacıyla 724 kişilik bir veri seti üzerinde doğrulayıı faktör analizi yapılmıştır. Analiz, Lisrel 9.30 programında gerçekleştirilmiştir.

\section{Bulgular}

Tablo 6, 43 maddelik Öğretmenlik Mesleği Etik Ölçeğinin maksimum olasılık kestirimlerini ve çoklu korelasyon karesi (R2) değeri ve ilişkinin manidarlı̆ını gösteren t değerlerini göstermektedir. Şekil 2, doğrulayıcı faktör analizi modelini göstermektedir.

Model uyumu, Hu ve Bentler'in (1999) iki indeks gösterme stratejisi kullanılarak ölçülmüştür. Standardize edilmiş kök ortalama kare artık (SRMR) kullanılmıştır ve bu kök ortalama kare yaklaşım hatası (RMSEA), karşılaştırmalı uyum indeksi (CFI), normlaştırılmamış uyum indeksi (NNFI), normlaştııımış uyum indeksi (NFI) ve göreli uyum indeksi (RFI) ile desteklenmiştir. Tablo 7'de görüldüğü gibi ki-karenin serbestlik derecesine oranı= $\mathrm{X} 2(860)=3338.32, \mathrm{p}<0.01$, kök ortalama kare yaklaşım hatası $(\mathrm{RMSEA})=.06$; Standardize edilmiş kök ortalama kare artık $(\mathrm{SRMR})=.06$; karşılaştırmalı uyum indeksi $(\mathrm{CFI})=.95$; uyum iyiliği indeksi $(\mathrm{GFI})=.69$; normlaştııılmamış uyum indeksi $(\mathrm{NNFI})=.94$; normlaştırılmış uyum indeksi $(\mathrm{NFI})=.94$; göreli uyum indeksi (RFI) $=.93^{\prime}$ tur. Şekil 2, ölçek maddelerinin lamda (faktör yük) değerlerine ilişkin yol grafiğini göstermektedir.

Ölçeğin iç tutarlıık güvenirliğini saptamak amacıyla Cronbach alfa güvenilirlik katsayısı hesaplanmıştır. Ölçeğin Cronbach alfa güvenirlik katsayısı, ikinci çalışmada da. 96'dır. Bu bulgu, ölçeğin, öğretmen adaylarının mesleki etik algılarının belirlenmesine yönelik bir araç olarak, yüksek iç tutarlıık güvenirliğine sahip olduğunu ortaya koymaktadır.

Tüm maddelerin $t$ değerleri anlamlıdır ( $p<0.05)$. Bu da örtük değişken ve her bir madde arasındaki ilişkinin anlamlı olduğunu ve ölçekten herhangi bir madde çıkarılmasına gerek olmadığını göstermektedir. Uyum indeksleri, verinin, çalışma 1 'de ortaya konulan tek boyutlu modele uyum gösterdiğini ortaya koymaktadır. Tablo 7, 43 maddelik Öğretmenlik Mesleği Etik Ölçeğinin uyum indekslerini göstermektedir.

\section{Tartışma}

Çalışma 1 ile tek boyutlu, 43 maddelik Likert tipi bir ölçek elde edilmiştir. Çalışma 2, çalışma 1'de elde edilen tek boyutlu yapıyı test etmek amacıyla gerçekleştirilmiştir. Çalışma 2'nin sonuçları, tek boyutlu ölçeğin, öğretmen adaylarının öğretmenlik mesleğine yönelik algılarını ölçtüğünü doğrulamıştır. Sonuçlar, ayrıca, ölçeğin geçerli ve güvenilir bir araç olduğunu ortaya koymaktadır. 
Tablo 6.

Doğrulayıcı Faktör Analizi Sonuçları $(n=724)$.

\begin{tabular}{|c|c|c|c|}
\hline Madde No & Kestirim Değeri & $\mathbf{R}^{2}$ & $t$ değeri \\
\hline 1 & .27 & .13 & 6.94 \\
\hline 2 & .23 & .16 & 3.82 \\
\hline 3 & .21 & .08 & 3.86 \\
\hline 4 & .20 & .18 & 3.56 \\
\hline 5 & .32 & .27 & 6.03 \\
\hline 6 & .40 & .32 & 8.88 \\
\hline 7 & .21 & .26 & 3.03 \\
\hline 8 & .44 & .40 & 10.40 \\
\hline 9 & .34 & .26 & 7.30 \\
\hline 10 & .39 & .27 & 10.20 \\
\hline 11 & .44 & .33 & 12.20 \\
\hline 12 & .30 & .31 & 5.14 \\
\hline 13 & .36 & .29 & 6.39 \\
\hline 14 & .46 & .30 & 12.60 \\
\hline 15 & .41 & .51 & 9.91 \\
\hline 16 & .39 & .41 & 7.56 \\
\hline 17 & .30 & .26 & 5.18 \\
\hline 18 & .42 & .24 & 10.40 \\
\hline 19 & .45 & .37 & 10.80 \\
\hline 20 & .49 & .34 & 13.00 \\
\hline 21 & .34 & .37 & 5.65 \\
\hline 22 & .29 & .30 & 4.89 \\
\hline 23 & .30 & .38 & 4.88 \\
\hline 24 & .30 & .42 & 5.50 \\
\hline 25 & .28 & .34 & 4.92 \\
\hline 26 & .30 & .37 & 6.25 \\
\hline S27 & .38 & .37 & 8.56 \\
\hline S28 & .29 & .42 & 5.17 \\
\hline S29 & .37 & .39 & 7.50 \\
\hline S30 & .38 & .41 & 8.44 \\
\hline S31 & .36 & .47 & 8.87 \\
\hline S32 & .39 & .44 & 9.22 \\
\hline S33 & .36 & .43 & 7.18 \\
\hline S34 & .52 & .46 & 18.30 \\
\hline S35 & .51 & .37 & 13.00 \\
\hline S36 & .42 & .43 & 11.50 \\
\hline S37 & .46 & .48 & 13.40 \\
\hline S38 & .39 & .47 & 9.28 \\
\hline S39 & .48 & .45 & 16.20 \\
\hline S40 & .38 & .46 & 7.37 \\
\hline S41 & .46 & .44 & 14.10 \\
\hline S42 & .49 & .44 & 13.80 \\
\hline $\mathrm{S} 43$ & .40 & .45 & 8.14 \\
\hline
\end{tabular}


Sevinç Gelmez-Burakgazi, İclal Can - Uluslararası Eğitim Programları Dergisi, 8(2), 275-298

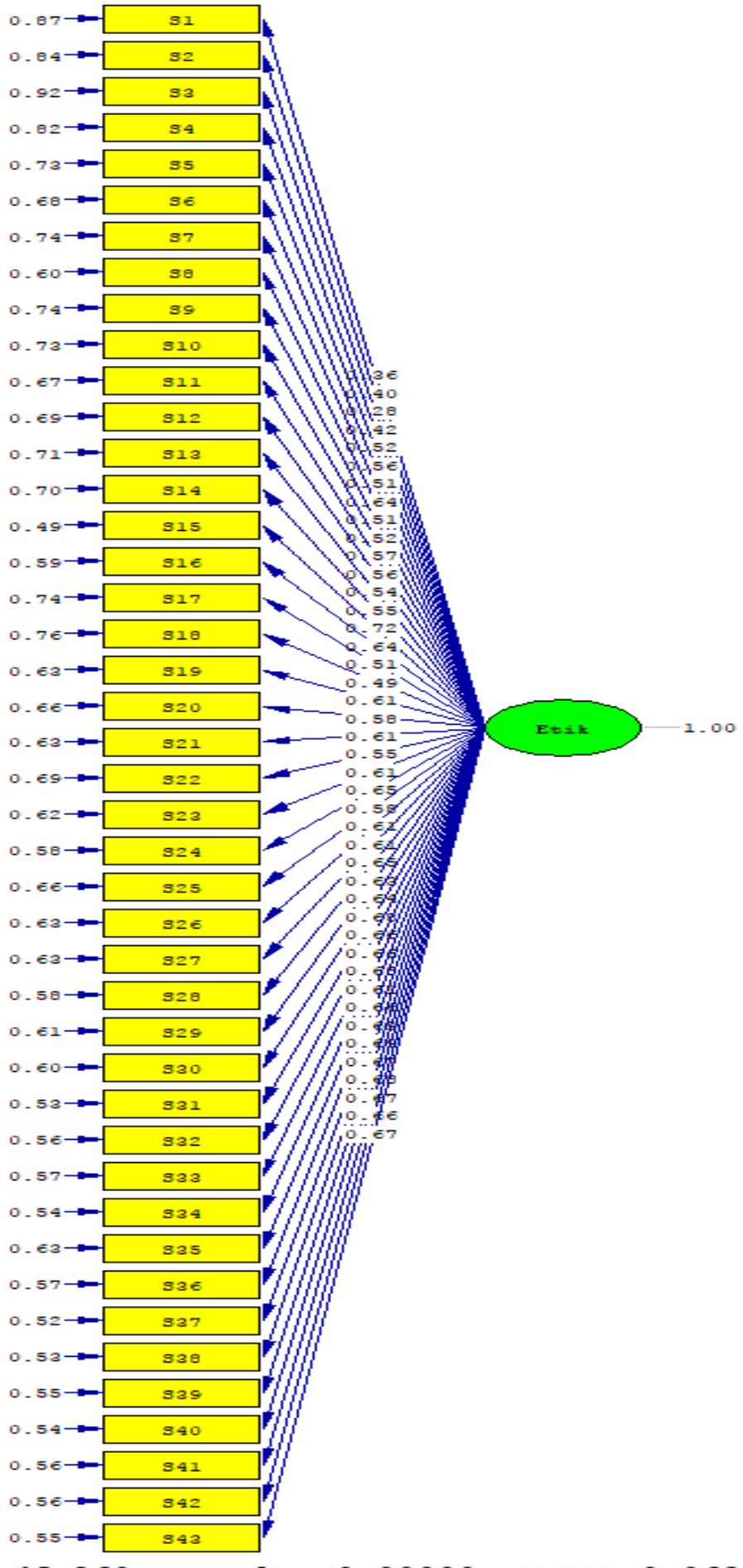

chi-square $=3338.32$,

Şekil 2. Doğrulayıcı faktör analizi modeli 
Tablo 7.

Öğretmen Adayları için Mesleki Etik Ölçeği Maddelerinin Faktör Yapısı Için Uyum Iyilik Indeksleri.

\begin{tabular}{lll}
\hline Uyum İyilik İndeksleri & Kabul Edilebilir Sınır & Değer \\
\hline $\mathrm{X}^{2} / \mathrm{sd}$ & $<5$ Orta düzeyde & $3338.32 / 860=3.88$ \\
$\mathrm{GFI}$ & $<3$ İyi uyum & .69 \\
$\mathrm{CFI}$ & $>0.90$ & .95 \\
$\mathrm{NFI}$ & $>0.90$ & .94 \\
$\mathrm{NNFI}$ & $>0.90$ & .94 \\
$\mathrm{RFI}$ & $>0.90$ & .93 \\
$\mathrm{SRMR}$ & $>0.85$ & .06 \\
RMSEA & $<0.08$ & .06 \\
\hline
\end{tabular}

Not. GFI = uyum iyiliği indeksi; $\mathrm{CFI}=$ karşılaştırmalı uyum indeksi; NFI = normlaştırılmış uyum indeksi; NNFI = normlaştırılmamış uyum indeksi; RFI = göreli uyum indeksi; SRMR = Standardize edilmiş kök ortalama kare artık; RMSEA = kök ortalama kare yaklaşım hatası

\section{Genel Tartışma}

Bu çalışmada, öğretmen adaylarının meslek etiğine yönelik algılarını tespit etmek amacıyla bir ölçek geliştirilmiş ve geçerliği test edilmiştir. Bu amaçla, ilgili alan yazın, öğretmenlik meslek etiğini ölçen mevcut ölçekler, öğretmen adayları ile yapılan beyin fırtınası oturumlarının sonuçları, MEB (2015) tarafından öğretmenler için belirlenen mesleki etik kodları, kültürel değerler ve normlar ve öğretmen eğitimcileri olarak mesleki tecrübe doğrultusunda 43 maddelik tek boyutlu bir ölçek geliştirilmiştir.

Ölçeği geliştirmek ve geçerliğini test etmek için iki çalışma yapılmıştır. Çalışma 1, ikinci faktörün özdeğerinden beş kat daha büyük bir özdeğere sahip olan varyansın \% 39.36'sını açıklayan tek faktörlü bir ölçek ortaya koymuştur. Ölçekten çıkarılan maddeler arasında, öğrencilere borç para vermek, öğrencilerden hediye kabul etmek, öğrencilerden para toplamak ve Facebook gibi sosyal paylaşım sitelerinde öğrencilerle arkadaş olmak gibi maddeler mevcuttur. Bu sonuçlar kısmen kültür ve etik arasındaki ilişki ile açıklanabilir (Sorokin, 2017). Hofstede (1983), kültürü “ortak zihinsel programlama” olarak tanımlamaktadır ve kültürel normlar etik kuralları etkileyip şekillendirebilir. Buradan hareketle, Türk öğretmen adaylarının bu maddeleri çoğunlukla doğru bulmuş olma olasılığından dolayı, maddelerin Türk bağlamında çoğunlukla çalışmadığı düşünülebilir. Bu sonuçlar, öğretmenlik mesleğinin kodlarının farklı ülkelerde farklı tonlarda ve farklı kodlarla yer alabileceğini öne süren McKelvie-Sebileau (2011) fikrini daha da desteklemektedir.

Çalışma 2'de, doğrulayıcı faktör analizi ile Çalışma 1'de üretilen tek boyutlu ölçek test edilmiştir ve doğrulanmıştır. GFI dışındaki tüm uyum indeksleri kabul edilebilir olduğu için, sonuçlar modelin veriye uyduğunu göstermektedir. Çalışma 1 ve Çalışma 2'nin sonuçlarına göre, 43 maddelik ölçek, öğretmen adaylarının meslek etiği algılarını incelemek için geçerli ve güvenilir bir araçtır. Ölçeğin Cronbach alfa katsayısı, 1. ve 2. çalışmada. 96'dır. Bu değer, yüksek iç tutarlılık güvenilirliğinin bir göstergesidir.

Alan yazında, öğretmenlerin etik algılarını araştıran pek çok ölçek bulunmaktadır (Aydoğan, 2011; Barrett, 2006; 2012; Kumar \& Kaur, 2014; Özbek, 2003; Öztürk Aynal, Kumandaş \& Ersanlı, 2013; Kumar \& Kaur, 2014; Poisson, 2009; Sevim, 2014; Tabachnick, Keith-Spiegel \& Pope, 1991; Yılmaz, 2005), ancak hizmet öncesi öğretmenlere yönelik sınırlı bir odak mevcuttur (Gözütok, 1999; Pelit \& Güçer, 2006; Yılmaz \& Altınkurt, 2009). Hizmet öncesi öğretmenlerin etik algılarını değerlendirmek için çok boyutlu bir yapıya işaret eden daha önceki çalışmaların aksine, bu çalışma ile öğretmen adaylarının etik algılarını incelemek için tek boyutlu bir yapı önerilmektedir, bu da Türk bağlamında veri toplayan Aydoğan'ın (2011) çalışması ile uyumludur.

Ölçek, öğretmen adaylarının öğretmen eğitiminde meslek etiği üzerine farkındalıklarını artırmak üzere geliştirilecek uygulamalarda ve/ya eğitim programlarında kullanılabilir. Geliştirilen ölçek aracılığıyla öğretmen adaylarının öğretmenlik mesleğine yönelik algıları tespit edildikten sonra, çalışma sonuçlarına göre eğitimler ve/ya uygulamalar geliştirilebilir. Bu çalışmanın bir sınırlıı̆̆ı, Çalışma 1 ve Çalışma 2'deki katılımcıların, sonuçların genellenebilirliğini sınırlayan uygun örnekleme yöntemi kullanılarak seçilmiş olmasıdır. Gelecekte yürütülecek çalışmalarda, ölçek tesadüfi örnekleme yöntemi kullanılarak daha geniş katılımcı kitlesine uygulanabilir.

\section{Bilgilendirme}

Bu çalışmanın bir bölümü, 4. Uluslararası Eğitim Programları ve Öğretim Kongresi'nde (ICCI-EPOK) bildiri olarak sunulmuştur (27-30 Ekim 2016, Antalya, Türkiye) 


\section{References}

Aydoğan, ì. (2011). Öğretmenlerin mesleki etik ilkelere uyma düzeylerinin öğrenciler tarafından algılanması. FIrat Üniversitesi Sosyal Bilimler Dergisi, 21(2).

Barrett, D. E., Headley, K. N., Stovall, B., \& Witte, J. C. (2006). Teachers' perceptions of the frequency and seriousness of violations of ethical standards. The Journal of Psychology, 140, 421-433. https://doi.org/10.3200/JRLP.140.5.421-433

Barrett, D. E., Casey, J. E., Visser, R. D., \& Headley, K. N. (2012). How do teachers make judgments about ethical and unethical behaviors? Toward the development of a code of conduct for teachers. Teaching and Teacher Education, 28(6), 890-898. https://doi.org/10.1016/j.tate.2012.04.003

Büyüköztürk, S. (2004). Veri analizi el kitabı. Ankara: PegemA Yayıncılık.

Campbell, E. (2000). Professional ethics in teaching: Towards the development of a code of practice. Cambridge Journal of Education, 30(2), 203-221. https://doi.org/10.1080/03057640050075198

Ei, S., \& Bowen, A. (2002). College student's perceptions of student-instructor relationship. Ethics \& Behavior, 12(2), 177-190. https://doi.org/10.1207/S15327019EB1202_5

Forsyth, D. R, O'Boyle Jr, E. H, \& McDaniel, M. A (2008). East meets west: A meta-analytic investigation of cultural variations in idealism and relativism. Journal of Business Ethics, 83, 813-833.

Gözütok, F. D. (1999). Öğretmenlerin etik davranışları. Ankara Üniversitesi Eğitim Bilimleri Fakültesi Dergisi, 32(1-2), 83-99.

Haynes, F. (1998) The ethical school. London: Routledge.

HEC (2007). Öğretmen yetiştirme ve eğitim fakülteleri (1982- 2007). Ankara: Yükseköğretim Kurulu. Retrieved from: http://www.yok.gov.tr/documents/10279/49665/aciklama_programlar/aa7bd091-9328-4df7-aafa2b99edb6872f

Hofstede, G. (1983). The cultural relativity of organizational practices and theories. Journal of International Business Studies, 75-89.

Hu, L., \& Bentler, P. M. (1999). Cutoff criteria for fit indices in covariance structure analysis: Conventional criteria versus new alternatives. Structural Equation Modeling, 6, 1-55. http:// dx.doi.org/10.1080/10705519909540118

Kumar, S. D., \& Kaur, S. (2014). Professional ethics grow with teaching experience: A study of women teachers in higher education institutions of Punjab. European Academic Research, 2(4), 5904-5922.

Lovat, T. J. (1998) Ethics and ethics education: professional and curricular best practice. Curriculum Perspectives, 18(1), 1-7.

Maxwell, B., \& Schwimmer, M. (2016). Professional ethics education for future teachers: A narrative review of the scholarly writings. Journal of Moral Education, 45(3), 354-371. https://doi.org/10.1080/03057240.2016.1204271

McKelvie-Sebileau, P. (2011). Patterns of development and use of codes of conduct for teachers in 24 countries. Série Ethique et corruption dans l'éducation. Paris: IIPE-UNESCO.

Miller, E.W. (2000). Ethics in higher education. In Miller et. al (Ed.), Ethics in Academia, (pp. 1-2). Pennsylvania: The Pennsylvania Academy of Science.

MoNE (Ministry of National Education). (2015). Öğretmenlik Mesleği Etik Ilkeleri. Retrieved from: http://askale.meb.gov.tr/meb_iys_dosyalar/2015_07/08040929_etmclernmesleketklkeler.pdf

Murphy, K. R. \& Davidshafer, C. O. (2005). Psychological testing: Principles and applications (6 ${ }^{\text {th }}$ ed.). Upper Saddle River, NJ: Prentice Hall.

Özbek, O. (2003). Beden eğitimi öğretmenlerinin mesleki etik ilkeleri ve bu ilkelere uyma düzeyleri. Unpublished Master's thesis, Ankara University.

Öztürk-Aynal, S. O., Kumandaş, H., \& Ersanlı, K. (2013). Okul öncesi öğretmenlerine yönelik mesleki etik ilkeleri ölçeği geliştirme çalışması. Ahi Evran Üniversitesi Kırşehir Eğitim Fakültesi Dergisi (KEFAD), 14(1), 429-442. 
Pelit, E. \& Güçer, E. (2006). Öğretmen adaylarının öğretmenlik mesleğiyle ilgili etik olmayan davranışlara ve öğretmenleri etik dışı davranışa yönelten faktörlere ilişkin algılamaları. Ticaret ve Turizm Eğitim Fakültesi Dergisi, 2, 95-119.

Poisson, M. (2009). Guidelines for the design and effective use of teacher codes of conduct. Ethics and Corruption in education Series. Paris: IIEP-UNESCO

Sevim, O. (2014). Akademik Etik Değerler Ölçeğinin Geliştirilmesi: Güvenirlik ve Geçerlik Çalışması. International Periodical for The Languages, Literature and History of Turkish or Turkic, 9(6), 943-957.

Singer, P. (1993). A companion to ethics. Oxford: Blackwell.

Sorokin, P. (2017). Social and cultural dynamics ( $1^{\text {st }}$ ed.). New York: Routledge.

Tabachnick, B. G., Keith-Siegel, P., \& Pope, K. S. (1991). Ethics of teaching: Beliefs and behaviors of psychologists as educators. American Psychologist, 46, 5, 506. http://dx.doi.org/10.1037/0003066X.46.5.506

Tabachnick, B. G., \& Fidell, L. S. (2007). Using multivariate statistics ( $5^{\text {th }}$ ed.). Boston: Pearson Education, Inc./Allyn \& Bacon.

Turkish Language Association, 2016

(2016). http://www.tdk.gov.tr/index.php?option=com_bts\&view=bts\&kategori1=veritbn\&kelimesec=118065

Weil, V. (2005). Standards for evaluating proposals to develop ethics curricula. Science and Engineering Ethics, 11, 501-507. https://doi.org/10.1007/s11948-005-0020-5

Yılmaz, E. (2005). Etik liderlik ölçeği'nin geçerlik ve güvenirlik çalışması. XIV. Eğitim Bilimleri Kongresi Bildiri Kitabı, 808-814.

Yılmaz, K. \& Altınkurt, Y. (2009). Öğretmen adaylarının mesleki etik dışı davranışlar ile ilgili görüşleri. İ̧̧ Ahlakı Dergisi, 2(2) 71-78. 
